\title{
Effect of the Sunflower Seed Oil (Helianthus annus L.) Addition as an Omega-6 Source in Snakehead Fish (Channa striata) Albumin Gel on Wound Closure
}

\author{
Thomas Triwiyono Yudo Husodo*, Eddy Suprayitno ${ }^{* *}$ \\ *Department of Fisheries Technology \\ Faculty of Fisheries and marine science \\ Brawijaya University Indonesia \\ thomas27@student.ub.ac.id \\ **Department of Fisheries Technology \\ Faculty of Fisheries and marine science \\ Brawijaya University Indonesia \\ eddysuprayitno@ub.ac.id
}

DOI: 10.29322/IJSRP.11.07.2021.p11541

http://dx.doi.org/10.29322/IJSRP.11.07.2021.p11541

\begin{abstract}
Gel is a semisolid or viscous preparation, which is non-sticky, easy to apply on the skin and easy to wash off. The application of snakehead fish albumin as a traditional medicine is usually found in the form of extracts (liquid or powder). Many do not like these extract preparations because of their pungent aroma and easy to stale. Gel preparations are an alternative in utilizing albumin into products that are easy to apply, by means of smearing. Sunflower seed oil is added as a source of omega- 6 which can speed up the wound closure process. The results of Phase 1 showed that different concentrations of sunflower seed oil affected the quality of albumin gel, namely $\mathrm{pH}$, viscosity, omega-6, protein content, fat content, and water content. The best albumin gel was obtained at a concentration of $6 \%$ snakehead fish albumin extract with the following results $\mathrm{pH} 6.8$, viscosity $4016 \mathrm{cP}$, omega-6 1.68\%, protein content $3.18 \%$, fat content $3.56 \%$, and water content $92.64 \%$. Research Phase 2 showed that the highest fatty acid in the preparation was linoleic acid $(\mathrm{C} 18: 2, \mathrm{n}-6) 1.68 \mathrm{~g} / 100 \mathrm{~g}$. Observation of wound closure showed that experimental animals given the best concentration of $6 \%$ albumin gel experienced the fastest wound closure where wound closure reached $70 \%$ on the 7 th day.
\end{abstract}

Index Terms- albumin, gel, omega-6, sunflower seed oil, wound closure

\section{INTRODUCTION}

Consumption of snakehead fish extract can increase albumin levels and accelerate the wound healing process after surgery. Albumin is a globular protein that functions to regulate osmotic pressure in the blood (Marjiyanto et al., 2013). In addition to albumin, other components are needed in wound closure, namely omega-6, omega-3 fatty acids and collagen (Nicodemus et al., 2014). Omega-6 and omega-3 fatty acids are PUFA (Polyunsaturated Fatty Acid) which can induce the inflammatory phase and help the synthesis of collagen for the construction of new skin tissue. Source of omega- 6 fatty acids from sunflower oil and omega- 3 fatty acids from flaxseed oil. Sunflower seed oil is rich in omega-6 reaching 69\%, which is the highest among other dietary sources (Khan et al., 2015).

Albumin taken orally in the form of extracts (liquid or powder) has a disadvantage, namely its very fishy aroma and easily degraded. To overcome this problem, albumin extract is processed into gel preparations. Gel is a unique material that is rigid and elastic which is widely applied in the fields of cosmetics, medicine, biomaterials, and food technology. Compared to creams and ointments, gels have a higher water content, allowing the skin to absorb drugs more quickly and helping the migration of drugs through the skin tissue (Rehman and Zulfakar, 2014). This study aims to develop snakehead fish albumin which is added as a source of omega-6, namely sunflower seed oil into a gel preparation to make it easier to use in wound closure.

\section{MATERIALS AND METHODS}

\subsection{Material}

The raw materials used for the manufacture of albumin extract are snakehead fish (Channa sriata), ingredients for collagen production, namely grouper skin (Ephinephelus sp.), $\mathrm{NaOH}$, acetic acid and aquades. The ingredients for the manufacture of albumin 
gel are albumin extract derived from snakehead fish, collagen, sunflower seed oil, linseed oil and fillers in the form of HPMC (Hydroxypropyl Methylcellulose), propylene glycol, methyl paraben, propyl paraben, TEA (Trieethanolamine), and aquades.

This research method is an experimental method and is carried out in 2 stages. Phase 1 research aims to obtain the optimal concentration of sunflower seed oil added to albumin gel in order to obtain the best gel quality. While the second stage of the study aimed to observe the wound closure process in experimental animals using albumin gel with the best quality compared to negative and positive controls.

\subsubsection{Albumin Extraction}

The production of albumin extract begins with the preparation of raw materials, namely the snakehead fish is turned off, then weeded, filleted, diced and washed. Furthermore, the meat is weighed 250 grams, then put into a steamer with a temperature of $70 \mathrm{oC}$. The snakehead fish meat is steamed for 30 minutes. After that the meat is filtered and the filtrate is taken. Snakehead fish albumin extract is ready to use.

\subsubsection{Collagen}

The production of collagen begins with preparing the skin of the grouper whose scales have been removed, then cut into $1 \mathrm{x} 1$ $\mathrm{cm}$. Then the grouper skin was soaked in $0.1 \mathrm{M} \mathrm{NaOH}$ for 24 hours with a ratio of skin and solution of 1:10. After that, the grouper skin was neutralized with distilled water. Then soaked in acetic acid with a ratio of 1:10 for 24 hours. Then filtered and the filtrate was taken. After that, precipitation was carried out with $0.9 \mathrm{M} \mathrm{NaCl}$ for 24 hours. Then centrifuged at $3500 \mathrm{rpm}$ for 20 minutes. Then dialysis with $0.5 \mathrm{M}$ acetic acid in a ratio of 1:10. After that it is inserted into the cellophane membrane. Then soaked in $0.1 \mathrm{M}$ acetic acid solution for 6 hours. Then soaked with distilled water until it reaches a neutral $\mathrm{pH}$. After that the collagen is ready to use.

\subsubsection{Albumin Gel}

The manufacture of albumin gel begins with dissolving HPMC with distilled water, then adding TEA. Methyl paraben and propyl paraben were dissolved in propylene glycol, then albumin extract was added followed by sunflower seed oil (3\%, $4.5 \%$, and $6 \%$ concentrations). Next the addition of collagen and linseed oil. After that all the ingredients are mixed and added with distilled water to $100 \mathrm{ml}$. Albumin gel was analyzed physically (pH and viscosity), chemically (omega-6, protein, fat, and water), and organoleptically.

\section{RESULT AND DISCUSSION}

\section{$3.1 \mathrm{pH}$}

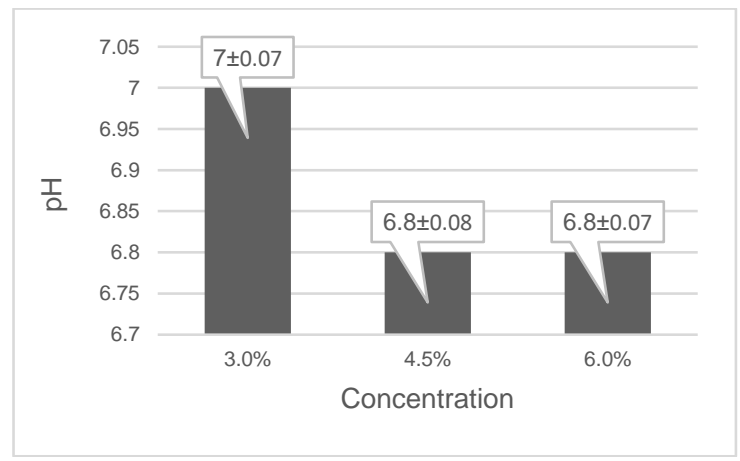

Figure 1. pH of Albumin Gel

Albumin gels with different concentrations of sunflower seed oil produced different $\mathrm{pH}$ values. At a concentration of $3 \%$, the $\mathrm{pH}$ value was 7 , the $4.5 \%$ concentration was 6.8 , and the $6 \%$ concentration was obtained with a $\mathrm{pH}$ of 6.8 . The highest $\mathrm{pH}$ value was at the lowest concentration of $3 \%$ with a $\mathrm{pH}$ value of 7 , while the lowest was obtained at a concentration of $6 \%$ at 6.8 . The $\mathrm{pH}$ value of the albumin gel produced is still in the safe $\mathrm{pH}$ range for the skin, namely 5.8-7.2 (Vashist et al., 2015), so that the albumin gel does not irritate the skin or make the skin dry. 


\subsection{Viscosity}

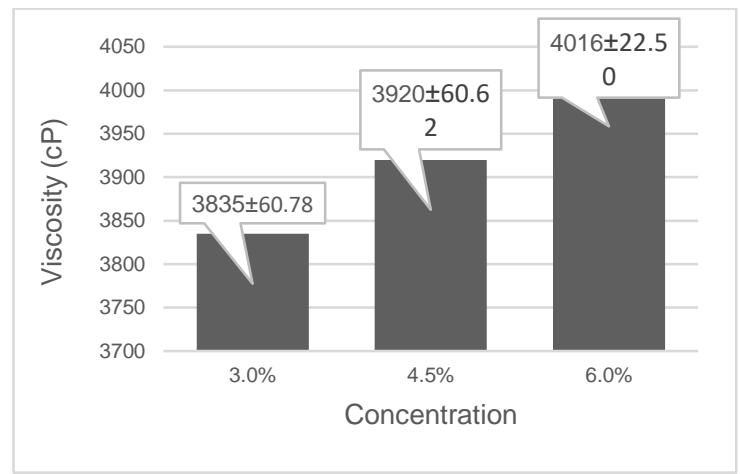

Figure 2. Viscosity of Albumin Gel

The gel viscosity value at a concentration of $3 \%$ was $3835 \mathrm{cP}$, at a concentration of $4.5 \%$ the viscosity value was $3920 \mathrm{cP}$, and at a concentration of $6 \%$ it was $4016 \mathrm{cP}$. The gel viscosity results that have the highest value are gels with a concentration of $6 \%$ sunflower seed oil at $4016 \mathrm{cP}$, and the lowest value at $3 \%$ concentration at $3835 \mathrm{cP}$. The viscosity range for a good gel is $2000-4000 \mathrm{cP}$ (Suryani et al., 2017).

\subsection{Omega-6 Content}

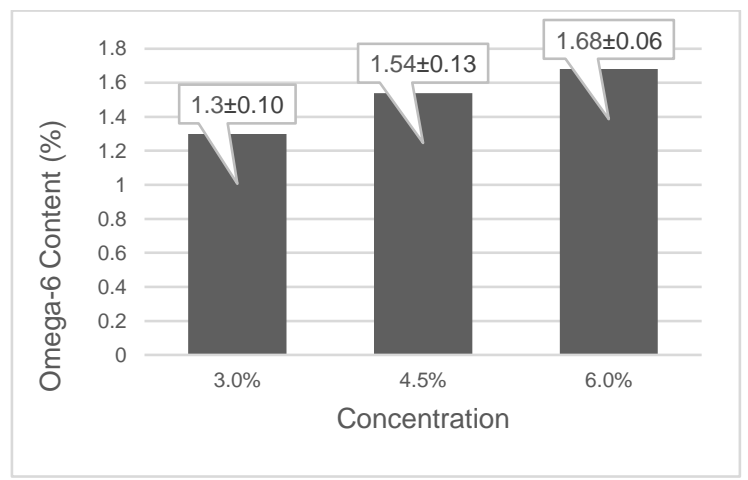

Figure 3. Omega-6 Content of Albumin Gel

Omega-6 levels at 3\% sunflower seed oil concentration were $1.3 \%, 4.5 \%$ concentration was $1.54 \%$, and $6 \%$ concentration was $1.68 \%$. The highest omega- 6 content was obtained at a concentration of $6 \%$, which was $1.68 \%$, while the lowest omega- 6 level was at a concentration of $3 \%$ at $1.3 \%$. The levels of omega- 6 in the albumin gel tested showed an increase along with the increase in the concentration of sunflower seed oil given.

\subsection{Protein Content}

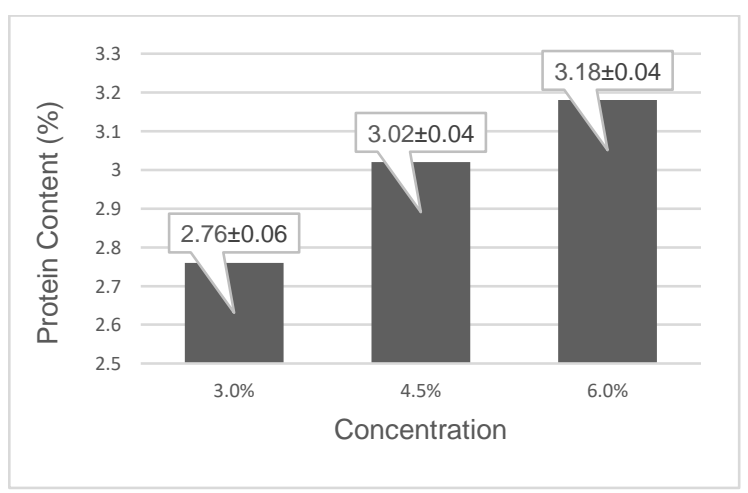

Figure 4. Protein Content of Albumin Gel

The protein content of albumin gel at a concentration of 3\% sunflower seed oil was $2.76 \%$, a concentration of $4.5 \%$ was $3.02 \%$, and a concentration of $6 \%$ had a protein content of $3.18 \%$. The highest protein content was obtained at a concentration of $6 \%$ at $3.18 \%$ This publication is licensed under Creative Commons Attribution CC BY. 
and the lowest at a concentration of $3 \%$ at $2.76 \%$. It can be concluded that the higher the concentration of sunflower seed oil, the greater the protein content. In addition, albumin also increases the protein content of the gel preparation.

\subsection{Fat Content}

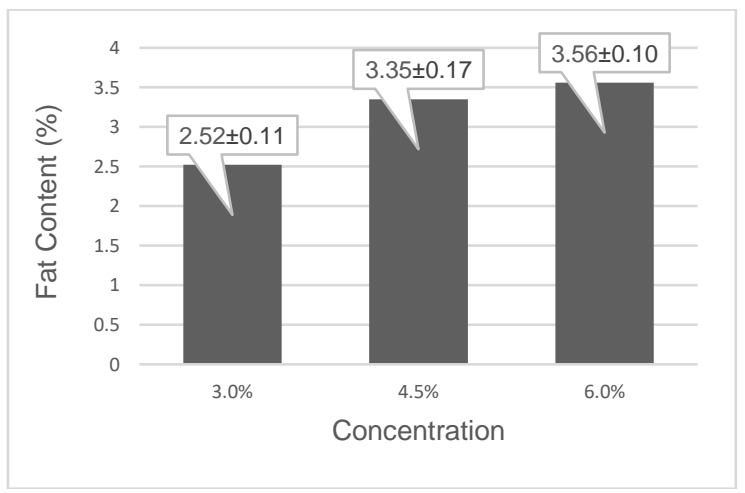

Figure 5. Fat Content of Albumin Gel

The fat content contained in the $3 \%$ sunflower seed oil concentration was $2.52 \%$, the $4.5 \%$ concentration was $3.35 \%$, and the fat content at the $6 \%$ concentration was $3.56 \%$. The highest fat content was found in gel albumin with $6 \%$ concentration of $3.56 \%$, while the lowest concentration of $3 \%$ was $2.52 \%$. The higher the concentration of sunflower seed oil, the higher the fat content. The fat content in albumin gel comes from sunflower seed oil as a source of omega- 6 and flaxseed oil.

\subsection{Water Content}

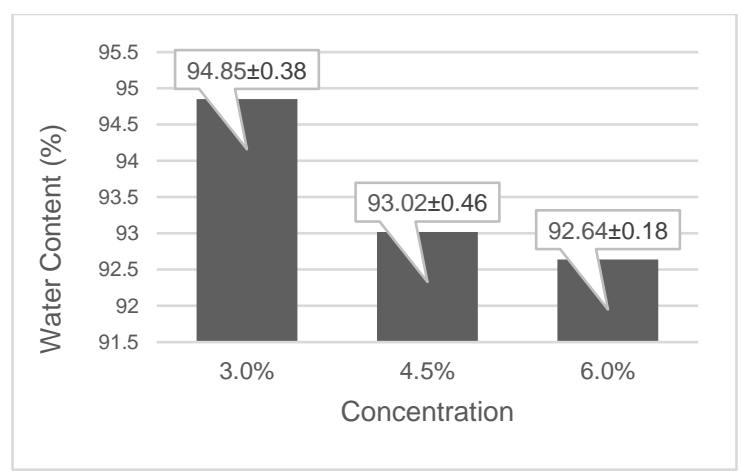

Figure 6. Water Content of Albumin Gel

The results of the water content at a concentration of $3 \%$ sunflower seed oil was $94.85 \%$, at a concentration of $4.5 \%$ it was $93.02 \%$, and a concentration of $6 \%$ was $92.64 \%$. The highest value of water content at a concentration of $3 \%$ is $94.85 \%$ while the lowest water content is at a concentration of $6 \%$, which is $92.64 \%$. The value of the water content decreases along with the increase in the concentration of sunflower seed oil which is applied to the manufacture of albumin gel. In addition to the presence of added fatty acids, the addition of sunflower seed oil will reduce the amount of distilled water added.

\subsection{Organoleptic}

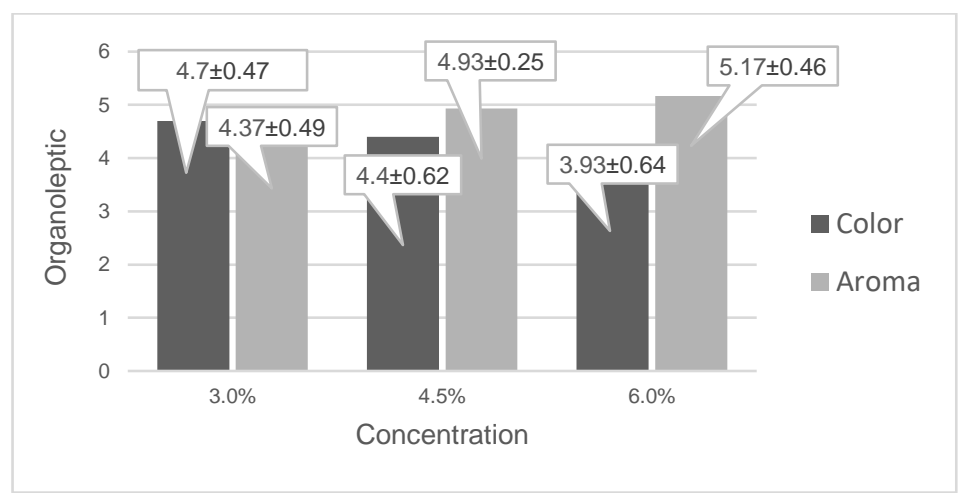

Figure 7. The result of Organoleptic 
The organoleptic assessment of albumin gel with different concentrations showed differences. In the treatment of sunflower seed oil concentration of $3 \%$ the color parameter showed a value of 4.7 , at a concentration of $4.5 \%$ it was 4.4 , and at a concentration of $6 \%$ it showed a value of 3.93. While the treatment of different concentrations of sunflower seed oil on aroma parameters showed different values. The aroma value of $3 \%$ concentration is $4.37,4.5 \%$ concentration is 4.93 , and at $6 \%$ concentration shows a value of 5.17 . The highest value of color parameters comes from a concentration of $3 \%$, amounting to 4.7. The concentration that has the lowest color value is the concentration of $6 \%$, which is 3.93 . While the highest value of the aroma parameter comes from a concentration of 6\%, which is 5.17. The concentration that has the lowest color value is a concentration of $3 \%$, which is 4.37 . This value indicated that the panelists liked the color of the albumin gel with a concentration of $3 \%$ sunflower seed oil, and the aroma of the albumin gel with a concentration of $6 \%$ sunflower seed oil. The lowest value obtained indicates that the panelists do not like the color and aroma of the albumin gel produced.

\subsection{Animal Testing}

After obtaining the optimal concentration of sunflower seed oil for the manufacture of the best quality albumin gel, namely a concentration of $6 \%$, the gel preparation was then tested on experimental animals to determine its effect on wound closure, a further test was the analysis of the fatty acid profile of albumin gel. Albumin gel with a concentration of $6 \%$ sunflower seed oil (GA6) was then compared with a negative control (K-) and a positive control $(\mathrm{K}+$ ). Experimental animal (mouse) were anesthetized and given a $2 \mathrm{~cm}$ cut on the side of the body. The wound closure process was observed for 7 days by calculating the length of the wound on the 3rd day, 5th day, and 7th day.

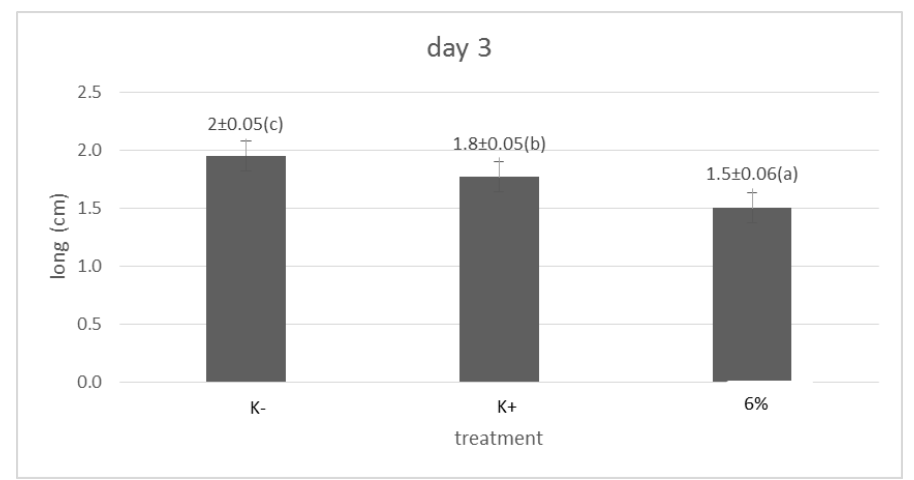

Figure 8. The Result of Day 3

On the 3rd day of treatment, each treatment showed different results of wound closure. The negative control treatment showed an average wound length of $1.8 \mathrm{~cm}$, the positive control treatment was $1.5 \mathrm{~cm}$, and the $6 \%$ albumin gel treatment was $1.5 \mathrm{~cm}$. The best wound closure on day 3 was obtained by positive control treatment and $6 \%$ albumin gel with a wound length of $1.5 \mathrm{~cm}$, while the longest wound closure was negative control treatment with a wound length of $1.8 \mathrm{~cm}$. It can be concluded that the wound closure process from the best treatment on the 3 rd day was $25 \%$.

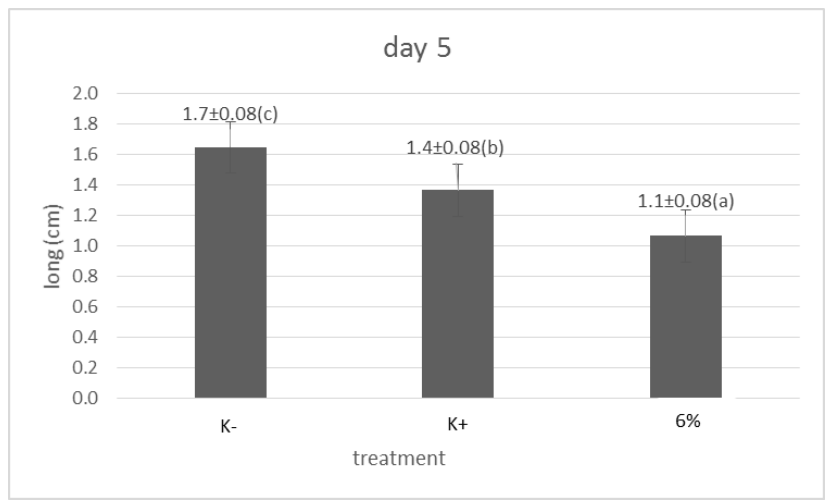

Figure 9. The Result of Day 5

Each treatment showed different results of wound closure on the 5th day. The negative control treatment showed an average wound length of $1.5 \mathrm{~cm}$, the positive control treatment was $1.3 \mathrm{~cm}$, and the $6 \%$ albumin gel treatment was $0.8 \mathrm{~cm}$. The best wound closure on day 5 was obtained from the gel albumin treatment with a concentration of $6 \%$ which was $0.8 \mathrm{~cm}$, while the longest wound closure was in the negative control treatment of $1.5 \mathrm{~cm}$. It can be concluded that the wound closure process from the best treatment on day 5 was $60 \%$. 


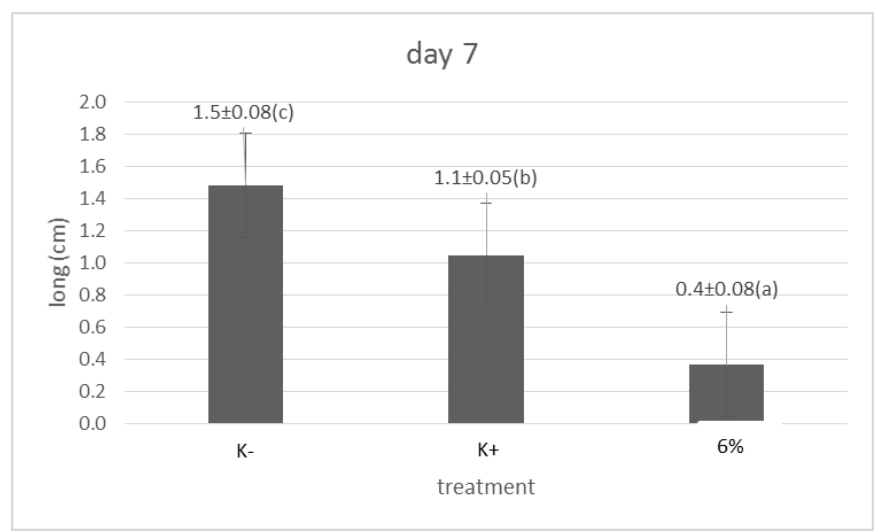

Figure 10. The Result of Day 7

Each treatment showed different results of wound closure on the 7 th day. The negative control treatment showed an average wound length of $1.2 \mathrm{~cm}$, the positive control treatment was $1.0 \mathrm{~cm}$, and the $6 \%$ albumin gel treatment was $0.6 \mathrm{~cm}$. The fastest wound closure on the 7 th day was obtained from the treatment with $6 \%$ albumin gel, which was $0.6 \mathrm{~cm}$, while the longest wound closure was in the negative control treatment of $1.2 \mathrm{~cm}$. It can be concluded that the wound closure process from the best treatment on the 7 th day was $70 \%$.

This result is lower than the study by Puspitasari and Suprayitno (2020), where wound closure using snakehead fish albumin gel on the 7 th day reached $80 \%$. However, when comparing wound closure on day 3 and day 5 , the wound closure process in this study occurred faster. This is related to the addition of omega-6 sources which act as mediators of thrombosis and inflammation (Simopoulos, 2016).

\subsection{Fatty Acid Profile}

Gel albumin with the addition of sunflower seed oil with a concentration of $6 \%$ was then analyzed for its fatty acid content to determine the highest type of fatty acid after the addition of sunflower seed oil as a source of omega- 6 . The fatty acid profile of albumin gel is as follows.

\begin{tabular}{cccc}
\multicolumn{4}{c}{ Table 1. Fatty Acid Profile of Albumin Gel } \\
\hline No. & Fatty Acid & Unit & Rate \\
\hline 1. & C 18:2 W6C (linoleic acid) & $\%$ & 1.6806 \\
2. & C 18:3 W3 (linolenic acid) & $\%$ & 1.1014 \\
3. & C 18:1 W9C (oleic acid) & $\%$ & 1.0541 \\
4. & C 16:0 (palmitic acid) & $\%$ & 0.5018 \\
5. & C 18:0 (stearic acid) & $\%$ & 0.2167 \\
6. & C 20:0 (arachidonic acid) & $\%$ & 0.0132 \\
7. & C 22:0 (behenic acid) & $\%$ & 0.0108 \\
9. & C 16:1 (palmitoleic acid) & $\%$ & 0.0105 \\
10. & C 14:0 (myristic acid) & $\%$ & 0.0087 \\
11. & C 20:1 (eicosenoic acid) & $\%$ & 0.0080 \\
12. & C 12:0 (lauric acid) & $\%$ & 0.0050 \\
13. & C 24:0 (lignoceric acid) & $\%$ & 0.0048 \\
14. & C 17:0 (heptadecanoic acid) & $\%$ & 0.0043 \\
\hline \multicolumn{5}{c}{ Total } & 4.6199 \\
\hline
\end{tabular}

The results of fatty acid profile analysis showed that the highest fatty acid content in albumin gel with a concentration of $6 \%$ was linoleic acid at $1.68 \%(\mathrm{C} 18: 2, \mathrm{n}-6)$ and the lowest was heptadecanoic acid at $0.0043 \%(\mathrm{C} 17: 0)$. The addition of sunflower seed oil enriches the fatty acid content of the albumin gel, especially omega-6, which can affect the wound closure process.

\section{CONCLUSION}

Sunflower seed oil with a concentration of $6 \%$ is the optimal concentration to produce the best albumin gel. includes a pH value of 6.8 , a viscosity value of $4016 \mathrm{cP}$, an omega- 6 content of 1.68 , a protein content of 3.18 , a fat content of 3.56 , and a water content of 92.64.

The results of the second stage of the study showed that different treatments for wounds had a significant effect on the wound closure process. Observations on experimental animals on day 3, day 5, and day 7, obtained the best wound closure results on day 7 of $75 \%$ of the initial wound length $(2 \mathrm{~cm})$ in experimental animals that were given albumin gel with addition of sunflower seed oil concentration of $6 \%$.

This publication is licensed under Creative Commons Attribution CC BY. 


\section{REFERENCES}

Khan, S., Choudhary, S., Pandey, A., Khan, M. K., \& Thomas, G. 2015. Sunflower oil: Efficient oil source for human consumption. Emergent Life Sciences Research. 1: 1-3. ISSN: 2395-6658.

Marjiyanto., Murtutik, L., \& Suwarni, A. 2013. Hubungan kadar albumin dengan penyembuhan luka pada pasien post operasi laparatomy di ruang mawar rumah sakit slamet riyadi surakarta. Jurnal Ilmu Keperawatan Indonesia. 6(3). ISSN: 2657-0076.

Nicodemus, M. Andrie \& S. Luliana. 2014. Uji efek penyembuhan luka sayat ekstrak ikan toman (Channa micropeltes) secara oral pada tikus putih jantan wistar. Jurnal Mahasiswa farmasi Fakultas Kedokteran UNTAN. 1(1):1-14. ISSN: 2551-9713.

Puspitasari, D. dan Suprayitno, E. 2020. The effect of giving fish cork albumin Gel (Channa striata) to the mice wound closure. International Journal of Scientific and Research Publications. 10(7). ISSN: 2250-3153.

Rehman, K., dan Zulfakar, M. H. 2014. Recent advances in gel technologies for topical and transdermal drug delivery. Drug Development and Industrial Pharmacy. 40(4): 433-440. ISSN: 0363-9045.

Simopoulos, A. P. 2016. An increase in the omega-6/omega-3 fatty acid ratio increases the risk for obesity. Nutrients. 8(3): 128. ISSN: 2072-6643.

Suryani, N., Mubarika, D. N., dan Komala, I. 2019. Pengembangan dan evaluasi stabilitas formulasi gel yang mengandung etil pmetoksisinamat. Pharmaceutical and Biomedical Sciences Journal. 1(1). ISSN: 2715-6702.

Vashist, S., S. K. Batra and S. Sardana. Formulation and evaluation of proniosomal gel of diclofenac sodium by using 32 factorial design. International Journal of Biopharmaceutics. 6(1): 48-54. ISSN: 0976 - 1047. 